\title{
Decreased Concentration
}

National Cancer Institute

\section{Source}

National Cancer Institute. Decreased Concentration. NCI Thesaurus. Code C117246.

Reduced ability to sustain attention. 